\title{
Research into Developing Innovation and Entrepreneurship Teaching Resources at Colleges and Universities
}

\author{
Feng Jiyuan \\ School of Information \& Control engineering \\ Shenyang Jianzhu University \\ Shenyang, China
}

\author{
Zhao Shengbin \\ School of Information \& Control engineering \\ Shenyang Jianzhu University \\ Shenyang, China
}

\begin{abstract}
As a new large country with abundant resources and a huge amount of population, China has annually increasing amount of graduates and is faced with new employment of situation. The party and the government pay more and more attention to the innovation and Entrepreneurship of college students in our country. In today's situation, innovation and entrepreneurship have very unusual significance.
\end{abstract}

Keywords-colleges and universities; innovation and entrepreneurship; teaching resources

\section{INTRODUCTION}

China, as a developing country, is facing the severe situation of competition and employment pressure in the world. Our party in the eighteen proposed: to encourage entrepreneurship, support youth entrepreneurship and entrepreneurship driven employment, and in the subsequent release of a number of major issues of the CPC Central Committee comprehensively deepen reform, the government has made clear the government's incentive to start a business, social entrepreneurship, and workers have the courage to start a new mechanism of entrepreneurship. This is an important guiding ideology in the new economic development and new situation. However, the current stage of China's education system and teaching methods, to some extent, restricts the implementation of this idea. This paper intends to start from the background of China's innovation and entrepreneurship, innovation and entrepreneurship education resources status quo, how to stimulate innovation and entrepreneurship and innovation and entrepreneurship education in Colleges and universities to carry out the significance of several aspects, explain the future trend of Chinese graduates in today's global economic environment.

\section{BACKGROUND OF INNOVATION AND ENTREPRENEURSHIP EDUCATION}

In 1989, at the International Conference on education, three passes: professional education, vocational education and entrepreneurship education. At this meeting, the "entrepreneurship education" was heightened to a new height. In China, it is very early to put forward the theory of innovation and entrepreneurship. In "the 9th five-year plan", it was the first time to put forward the transformation of economic growth mode. Afterwards, in the 17th National Congress of the Communist Party of
China, the policy of China's national economic development has been made clear: the transition from extensive economic growth mode to the new and innovative economic growth. To achieve the mutual coordination of "speed, quality and efficiency", "population, resources and environment" and "investment, consumption and exports", the emphasis is on optimizing the structure, improving the efficiency, reducing the efficiency and enhancing the environmental protection. The new direction of economic development is to realize the continuous innovation and progress of science and technology. At the same time, then the seventh session of the Fifth Plenary Session further clarified: to insist on the combination of technological innovation and economic development, as an important support for the new era of China's economic development.

With the rapid development of the new environment, the Chinese government has put forward higher requirements on the university innovation and entrepreneurship education of university students. In 2010, the Ministry of Education issued the opinions on promoting innovation and entrepreneurship education in Colleges and universities and their own business. Indicates China is making great efforts to the development of innovation and entrepreneurship education, improve the quality of education and teaching, to enhance China's overall international competitiveness, ease employment pressure and meet the needs of building an innovation oriented country.

\section{CURRENT SitUATION OF INNOVATION AND ENTREPRENEURSHIP EDUCATION IN COLLEGES AND UNIVERSITIES}

Innovation and entrepreneurship education, both the current economic development of the economic policy oriented factors, at the same time, also has the education itself to the growth of the people's service. That is the talent requirements. In twenty-first Century, it was no longer an extensive labor oriented economy, but the transition to a knowledge-based economy, the economic development and education for talent cultivation and talent growth of the interaction is increasingly obvious and prominent. University, as the new development and new economic growth situation of personnel training base, the role is also more prominent. The large-scale cultivation of 
innovative talents in the new situation is a new requirement of the society to the University.

However, many examples show that, in the current situation of China's colleges and universities, in the process of personnel training, there are still a lot of problems and obvious shortcomings. Such as; the spirit of innovation is not enough, a considerable part of the teachers and the students are sitting in the ivory tower, do not hear out of the window of thought. Innovation ability is low, hands-on ability is poor, more college students had to hand clothing, food to mouth life, the University as a paradise for enjoyment. And some students, although the body in the University, after graduation go directly home, devote themselves to their parents arms, dare not to contact with the society, dare to face the difficulties, to face the problem, fear foot. Although our country at the beginning of the new century has nine universities, such as Tsinghai University, as a pilot unit of innovation and entrepreneurship education in our country, and accumulated some experience. In 2012, the Ministry of Education issued the basic requirements (for Trial Implementation) of general undergraduate education, and required the national institutions of higher learning to carry out the compulsory course for all students at the University. This is also the business practice of learning in the country to carry out learning. But with the actual operation and application of foreign countries is too big. Compared to China, so far, the United States has more than 50 universities through the establishment of innovative research institutions or centers, to promote its innovation and entrepreneurship education and innovation.

\section{How to Motivate College Students' CONSCIOUSNESS OF INNOVATION AND ENTREPRENEURSHIP}

The innovation and Entrepreneurship of university teaching resources development, not only in the development of innovation and entrepreneurship resources, but also should pay more attention to a part of the deeper, and this part is the core part of the implementation of the students. Then enough resources, if there is no use of executive body of students at the end of the day, only the theory on paper. In today's economy, it is a highly intellectual economy era, the development of economy and the innovation of science and technology. But how to strengthen the implementation of the main, many people have mentioned, but many people are difficult to consider the basis of its. How to cultivate and stimulate students' innovative consciousness and innovative ideas, how to stimulate college students in the future economic and social development of a strong sense of entrepreneurship, which is also the deep meaning of the exploration of educational resources in the innovation and entrepreneurship education in Colleges and universities. From little acorns, the most important thing is the foundation. Without a good foundation, it is also difficult for good ideas and spirit to prop up the building of the venture. How deep to stimulate innovation and entrepreneurship awareness of students, when the "peel fraction", see the inherent nature. The analysis is intended to be conducted from the following angles.

\section{A. See Innovation at Colleges Outside Colleges}

\section{1) From the Perspective of Students}

Students are the masters of the future, the future of the support and successor, so, the scientific and innovative requirements of the implementation of the main, but also become more important. But in the real society, a lot of discordant sounds and factors are affecting the subject's progress and development over a long period of time. Since the last century eighty's family planning, the only child more and more, a lot of parents due to the young time to eat some bitter, no longer let a young generation of hardship, the children holding in the hand, containing in the mouth. Do not let the child do everything, and the child is the little prince, the little princess. And now the new century, more children are being protected by the whole family, spoiled. Even if the school manual production should be completed by the parents, and household chores, it is never left. "Score first" philosophy, since childhood, parents have been taught, no power, no independent thinking, everything has the protection of others, even in the choice of the University, the choice of professional do not have their own ideas. There are some students, there is no opportunity to face setbacks and difficulties, the school is the parents of the car to send, even though the University, are rare to their own independent school, a rare opportunity to go out of their own, but also to a certain extent, affect the students' independence and innovation. Many students attend college only to complete the tasks while not knowing the pressure in their future employment. Their parents instill their thoughts onto their minds in everything, so in the innovation and entrepreneurship education, they lack motivation, their own thoughts and ideals.

\section{2) From the Perspective of Parents}

Parents are the first teachers of the children, the German educator once said, the fate of a country is not in the hands of those in power, but in the hands of the mother, can be seen, the role of parents in the education process has irreplaceable role. However, due to the special situation of our country, in family education, many parents do not know how to educate their children. Think bitter from snacks, or now in the new century, many young parents also didn't eat bitter, with the grandma and grandpa, spoiled, let the children grew up living a "clothing to hand food to mouth," carefree life. In the home or school, labor is not willing to let the children do their homework, children as long as the exam is good, is the perfect. Greenhouse rearing of the child grew up believing that, of course, the young people the fight and face all books have curiosity and thinking is gradually fading. Mechanical cultivation mode, cultivate a high degree of low energy "good students", to a certain extent, is caused by the waste of learning resources. Therefore, although the state in the development of innovation and entrepreneurship education at the same time, in the face of this serious constraints, it should also increase investment promotion efforts, so that parents can be young and social thinking in the future, so as to cultivate more innovative and creative generation of new generation.

\section{3 ) From the Perspective of Basic Education}

The integration of educational resources in Colleges and universities, especially the innovation and the development of the venture capital, is the foundation and accumulation of the basic education. In the process of 
running a university, the students should pay more attention to the education idea of basic education in the face of the students' lack of innovation and entrepreneurship. Fractional oriented schools, often now many schools to a one-sided path, ignoring the country's labor courses, one-sided in order to improve the entrance rate as a guide, as a measure of the score of students excellent or not an important indicator. Therefore, the university should strengthen cooperation with the basic education, comprehensive understanding of the current situation and problems of basic education. The State Education Department, as a competent and coordinating the teaching resources of the Department should be actively cooperate with colleges and universities to do indepth research, actively sought in the process of education, cultivate students hands-on brain marching, a full range of "moral, intellectual, physical, aesthetics and labor development in an all-round way. Recognize the current social progress and development of the new situation, actively adapt to the current reform and development of innovation and entrepreneurship education in Colleges and universities, for the scientific and technological innovation oriented society's economic construction and the harmonious development of socialism more and better training of innovative talents.

\section{B. How Colleges Motivate and Cultivate College Students' Innovation and Entrepreneurship Consciousness}

Colleges and universities are the cradle of national and social training talents and the most direct organizer of the social and national transport personnel. University Students in the university to stimulate innovation and entrepreneurship awareness, can not only be limited to the current university campus internal and limited to the existing university resources, but should be free to look at the overall situation, from the grassroots level. Focus on the whole society, from the students themselves, parents and basic education in all aspects, to seek the global, to seek a world". At the same time, the university should strengthen cooperation to build the whole society's healthy education teaching mode, the full range of training students' innovative consciousness and innovative ideas, for the country to cultivate a large number of outstanding innovative talents, for the country to build innovative society of the Chinese dream to provide a strong guarantee

In self construction, the university should emancipate the mind actively, and increase the intensity of reform. In innovation and entrepreneurship education, colleges and universities should do a good job in the construction of curriculum system, strengthen the construction of teaching staff and ensure that social practice is carried out. At the same time, the policy can not rigidly adhere to a theorem or a certain kind of theory, but should actively carry out flexible and diverse measures.

Curriculum setting is an important step in innovation and entrepreneurship education. Whether the curriculum is reasonable or not, directly affects the education and teaching resources to the most full use, so in the course of innovation and entrepreneurship education, the organization department should be reasonable arrangements, fully mobilize all kinds of educational resources, and pay attention to the combination of practical and educational theory, and flexible use of teaching, emphasizing the importance of practice, not a mere formality. To establish and improve the practice platform, at the same time, it should actively study the current situation of regional economic development, study the relationship between regional economy and innovation and entrepreneurship education, and seek the integration points, so as to realize the curriculum setting mechanism based on social needs.

. Establish a sound incentive mechanism. As the saying goes "heavily, there must be brave, incentive mechanism, plays a fundamental role in the process of College Students' innovation and entrepreneurship. Institutions of higher learning, to the innovation and entrepreneurship education, as the purpose of running the school, to develop students' innovation and entrepreneurship to stimulate students' innovation and entrepreneurship, improve students' ability to innovate. To encourage and guide students to lead innovation and creative thinking out of the gate, and actively with the social practice, combined with the practice of enterprises, a powerful source of power. In the scholarship setting, also should go out of the classroom, into practice, form a good, sound incentive mechanism in order to make more college students to participate in, and more with a positive attitude to participate in innovation and entrepreneurship.

Establish and improve the teaching evaluation system of multi angle. In the face of innovative curriculum settings, can not in accordance with the traditional sense of a test score Chadian world "examination method, should mobilize the enthusiasm of the students and play a good student's subjective initiative, let the students participate in practice, carry out the combination of the first and second classroom teaching, the way, the formation of complementary knowledge and complementary mechanisms. In the assessment, we should carry out all aspects of the assessment, including the written examination, interview, special discussion, papers and reports and other aspects of the comprehensive evaluation.

Improve the construction of teacher's team of innovation and entrepreneurship education. Teachers, as a positive guide for college students' innovation and entrepreneurship education, at the same time, for the characteristics of innovation and entrepreneurship education practice, to strengthen the construction of innovation and entrepreneurship teachers. In the construction of teachers, to carry out a variety of forms of construction programs, such as strengthening the cooperation between enterprises, actively recruit entrepreneurs from outside the school, entrepreneurs or other entrepreneurs, to school as a part-time teacher. Completed the strategic partnership between schools and enterprises, and actively encourage teachers to enterprises participate in practical research, the latest situation of enterprise contact developments. It can also integrate the enterprise project case into the classroom, to promote students to actively participate in. In the cooperation between the school, and actively take the way to go out and introduce to encourage teachers out of school, and actively participate in other schools of innovation and entrepreneurship education. Let the mutual cooperation among teachers in various fields, sharing the results. 


\section{CONCLUSION}

At this stage, the innovation and entrepreneurship education in Colleges and universities, the development of education resources, the need to establish and improve the relevant policies of the national government, in a harmonious and standardized environment, orderly conduct. At the same time, each department needs to coordinate each other, and each area is coordinated with each other. Make use of the existing resources to the maximum extent, and to find out the future resources.

\section{REFERENCES}

[1] Yu En'de. Research into Dveloping Teaching Resources Combining Entrepreneurship Education and Innovation Education [J]. The Science Education Article Collects, the 10th edition of 2012: 42-42.

[2] Zhan Bihua, Zhu Shina, Tianyuan ,etc. Research into Comparison between the Current Situations of Innovation Teaching Resources and Entrepreneurship Teaching Resources [J]. Higher Medical Education in China, the 11th edition of 2009: 49-50.

[3] Innovation and Entrepreneurship Education Course for College Students [M], Hou Wenhua-Science Press, 2012, 12-19.

[4] Han Baocheng, Liu Mengyu, Liu Tongqi, Sun Minjuan, Xue Jun. Research into Exploring Changing Innovation and Entrepreneurship Education at Colleges into Entrepreneurship Practice [J] New Economy, 2015,Z2:154.

[5] Liu Gang, Li Qingliang, Wang Qingcai, Zhan Hui. The exploration and practice of innovation and entrepreneurship education in forestry science and Universities -- Taking the Forestry College of Shandong Agricultural University as an example [J]. Journal of Zhangjiakou Vocational and Technical College, 2013,02:11-13.

[6] Chinese University "integration" innovation and Entrepreneurship Education [M], Wu Jinqiu-Heilongjiang People's Press, 2003.

[7] Innovation and Entrepreneurship Education [M], Chen Jingliang, Fudan University Press, 2012. 